\title{
Spirulina platensis Lacks Antitumor Effect against Solid Ehrlich Carcinoma in Female Mice
}

\author{
Waleed Barakat, ${ }^{1,2}$ Shimaa M. Elshazly, ${ }^{1}$ and Amr A. A. Mahmoud ${ }^{1}$ \\ ${ }^{1}$ Department of Pharmacology, Faculty of Pharmacy, Zagazig University, Zagazig 44519, Egypt \\ ${ }^{2}$ Department of Pharmacology, Faculty of Pharmacy, Tabuk University, Tabuk 71491, Saudi Arabia \\ Correspondence should be addressed to Amr A. A. Mahmoud; aamahmoud@pharmacy.zu.edu.eg
}

Received 20 May 2015; Revised 4 August 2015; Accepted 9 August 2015

Academic Editor: Antonio Ferrer-Montiel

Copyright (c) 2015 Waleed Barakat et al. This is an open access article distributed under the Creative Commons Attribution License, which permits unrestricted use, distribution, and reproduction in any medium, provided the original work is properly cited.

\begin{abstract}
Spirulina is a blue-green alga used as a dietary supplement. It has been shown to possess anti-inflammatory, antioxidant, and hepatoprotective properties. This study was designed to evaluate the antitumor effect of spirulina (200 and $800 \mathrm{mg} / \mathrm{kg}$ ) against a murine model of solid Ehrlich carcinoma compared to a standard chemotherapeutic drug, 5-fluorouracil (20 mg/kg). Untreated mice developed a palpable solid tumor after 13 days. Unlike fluorouracil, spirulina at the investigated two dose levels failed to exert any protective effect. In addition, spirulina did not potentiate the antitumor effect of fluorouracil when they were administered concurrently. Interestingly, their combined administration resulted in a dose-dependent increase in mortality. The present study demonstrates that spirulina lacks antitumor effect against this model of solid Ehrlich carcinoma and increased mortality when combined with fluorouracil. However, the implicated mechanism is still elusive.
\end{abstract}

\section{Introduction}

Cancer is considered one of the leading causes of death worldwide, accounting for approximately 8.2 million deaths in 2012. Success of cancer chemotherapy is limited by druginduced adverse effects and multidrug resistance $[1,2]$. Therefore, there is a growing interest in identifying antitumor agents of natural sources, which are effective and produce fewer side effects than the conventional chemotherapeutic drugs. Actually, many of the currently used anticancer agents originate from natural sources, such as marine organisms and plants $[3,4]$.

Spirulina (Arthrospira platensis) is a blue-green alga used as a dietary supplement. It is rich in proteins, carotenoids, polyunsaturated fatty acids, vitamin B complex, vitamin E, and minerals. Additionally, it possesses other potent antioxidants such as spirulans, C-phycocyanin, and allophycocyanin $[5,6]$.

Spirulina phycocyanin has been shown to possess antiinflammatory, antioxidant, and hepatoprotective properties [7-9]. In addition, different studies demonstrated the potential anticancer activity of spirulina in different experimental models [10-12].
Ehrlich ascites carcinoma (EAC) is an undifferentiated carcinoma, which is characterized by rapid proliferation, high transplantable capability, and short life span [13]. EAC bears resemblance to human tumors; therefore, the solid and the ascetic forms of this tumor are frequently utilized to evaluate the antitumor activity of different products $[14,15]$.

Relying on the aforementioned, the present study was conducted to evaluate the effect of spirulina against Ehrlich solid tumor induced experimentally in mice. To our knowledge, this is the first report that describes the antitumor effect of spirulina in this experimental model of EAC solid tumor. In our attempt, we compared the effects of spirulina to a reference chemotherapeutic drug, fluorouracil, and examined the effect of their combined administration as well.

\section{Materials and Methods}

2.1. Animals. Adult female Swiss albino mice $(23 \pm 2 \mathrm{~g})$ were used in the current study. Mice were acclimatized for one week before starting experiments. They were housed in stainless steel cages ( 5 mice/cage) and kept at controlled temperature $\left(23 \pm 2^{\circ} \mathrm{C}\right)$, humidity $(60 \pm 10 \%)$, and light/dark $(12 / 12 \mathrm{hr})$ cycle. Animals had free access to food and water. 
2.1.1. Ethical Statement. Experimental design and animal handling procedures were approved by the local authorities at the Faculty of Pharmacy, Zagazig University, Zagazig, Egypt-ECAHZU (Ethical Committee for Animal Handling at Zagazig University). Every effort was made to reduce the number of animals and their suffering.

2.2. Drugs. Spirulina tablets, containing $100 \%$ Spirulina platensis microalgae powder, were obtained from Allcura Naturheilmittel (Wertheim, Germany). 5-Fluorouracil (50 mg/mL ampoules) was obtained from Pharco Pharmaceuticals (Egypt). All other chemicals were of analytical grade. Spirulina tablets were manually crushed, ground, and then suspended in $1 \%$ gum acacia in distilled water just before administration.

2.3. Induction of Ehrlich Solid Tumor. On the day of induction (day 0), EAC cells were collected from the ascitic fluid of a female Swiss albino mouse bearing 8-10-day-old ascitic tumor obtained from the National Cancer Institute (Cairo, Egypt). The ascitic fluid was diluted with normal saline (1:10). Solid tumors were induced by intramuscular inoculation of $0.2 \mathrm{~mL}$ of ascitic fluid, containing approximately $2.5 \times 10^{6}$ EAC cells, in the right thigh of the hind limb of each mouse [16].

2.4. Experimental Design. On the following day (day 1), EACbearing mice were randomly divided into six groups $(n=10$ each) as follows.

Group 1 (EAC). Mice were inoculated with EAC cells and received vehicle ( $1 \%$ gum acacia) by oral gavage daily from day 1 to 9 .

Group 2 (FU). Mice were inoculated with EAC cells and received 5-fluorouracil (20 mg/kg, i.p.) daily from day 1 to 9 .

Group 3 (SP200). Mice were inoculated with EAC cells and received spirulina $(200 \mathrm{mg} / \mathrm{kg})$ suspended in $1 \%$ gum acacia in distilled water by oral gavage daily from day 1 to 9 .

Group 4 (SP800). Mice were inoculated with EAC cells and received spirulina $(800 \mathrm{mg} / \mathrm{kg})$ suspended in $1 \%$ gum acacia in distilled water by oral gavage daily from day 1 to 9 .

Group 5 (FU/SP200). Mice were inoculated with EAC cells and received 5-fluorouracil (20 mg/kg, i.p.) plus spirulina $(200 \mathrm{mg} / \mathrm{kg})$ suspended in $1 \%$ gum acacia in distilled water by oral gavage daily from day 1 to 9 .

Group 6 (FU/SP800). Mice were inoculated with EAC cells and received 5-fluorouracil $(20 \mathrm{mg} / \mathrm{kg}$, i.p.) plus spirulina $(800 \mathrm{mg} / \mathrm{kg})$ suspended in $1 \%$ gum acacia in distilled water by oral gavage daily from day 1 to 9 .

Doses of spirulina and 5-fluorouracil were chosen based on previous studies $[17,18]$.

2.5. Blood Sampling, Assessment of Hematological Parameters, and Serum Preparation. On day 13, mice were anaesthetized with intraperitoneal injection of urethane $(2 \mathrm{~g} / \mathrm{kg})$, and blood samples were collected from the orbital sinus using heparinized microcapillary tubes as previously described [19]. Aliquot of blood was collected from each mouse into ethylenediamine tetra-acetic acid- (EDTA-) coated tubes for the analysis of hematological parameters using an automated analyzer Swelab Alfa (Boule Medical AB, Sweden). For serum preparation, another portion of blood was collected into microcentrifuge tube and then centrifuged at $3500 \mathrm{rpm}$ for $15 \mathrm{~min}$. Serum was stored at $-20^{\circ} \mathrm{C}$ and thawed just before use.

2.6. Determination of Tumor Weight and Volume. After blood collection, tumor-bearing thigh of each mouse was shaved; tumors were dissected, weighed, and photographed on a graph paper. Digital images were processed using ImageJ software (National Institutes of Health, USA) in order to determine the length $(\mathrm{mm})$ of the major and minor axes of the tumor. Tumor volume was calculated using the following formula [16]:

$$
\begin{aligned}
& \text { Tumor volume }\left(\mathrm{mm}^{3}\right) \\
& \quad=0.52 \times(\text { minor axis }) \times(\text { major axis })^{2} .
\end{aligned}
$$

2.7. Determination of Alanine Transaminase Activity. Serum alanine transaminase (ALT) activity was determined colorimetrically using an ALT-kit supplied by Diamond Diagnostics (Egypt), following the manufacturer's instructions. Absorbance of the final product was read using Jenway Genova spectrophotometer supplied by Bibby Scientific (Staffordshire, UK).

2.8. Histopathological Analysis. Specimens of tumors from different groups were excised and fixed in $10 \%$ phosphatebuffered formalin solution at room temperature. Specimens were dehydrated in graded ethanol (70-100\%), cleared in xylene, and embedded in paraffin. Paraffin-embedded tissue sections ( $5 \mu \mathrm{m}$ thick) were prepared, mounted on slides, and kept at room temperature. Thereafter, slides were dewaxed in xylene, hydrated using graded ethanol, and stained by hematoxylin and eosin (HE) dyes. The sections were examined under light microscope and photographed with a digital camera (Canon, Japan).

2.9. Statistical Analysis. All data were expressed as mean \pm standard error of mean (SEM). Statistical analysis was performed using GraphPad Prism software v.5 (GraphPad Software, Inc., La Jolla, CA, USA). The intergroup variation was measured by one-way analysis of variance (ANOVA) followed by Dunnett's posttest. A significant difference was assumed for values of $P<0.05$.

\section{Results}

3.1. Effect on Mortality Rate. As represented in Table 1, there was no difference in mortality rate between untreated EAC tumor-bearing mice and 5-fluorouracil-treated mice. Only one mouse died from each group. On the other hand, treatment of tumor-bearing mice with spirulina (200 and 


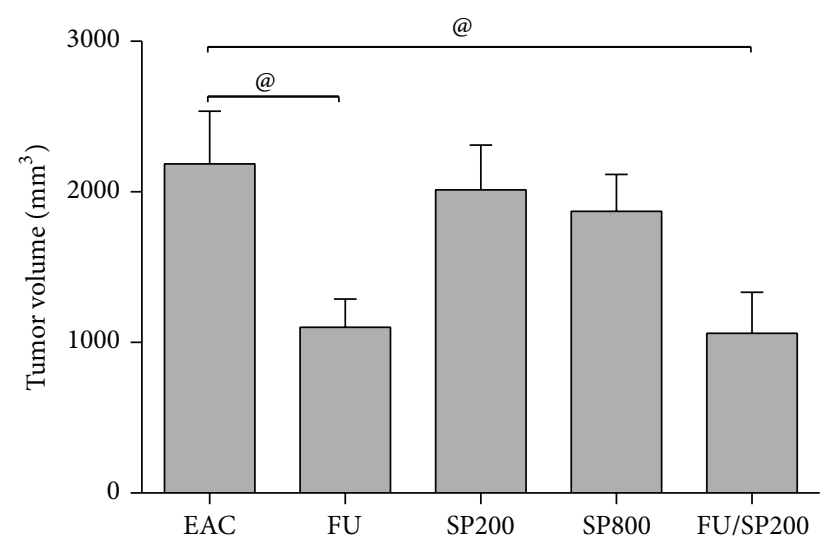

(a)

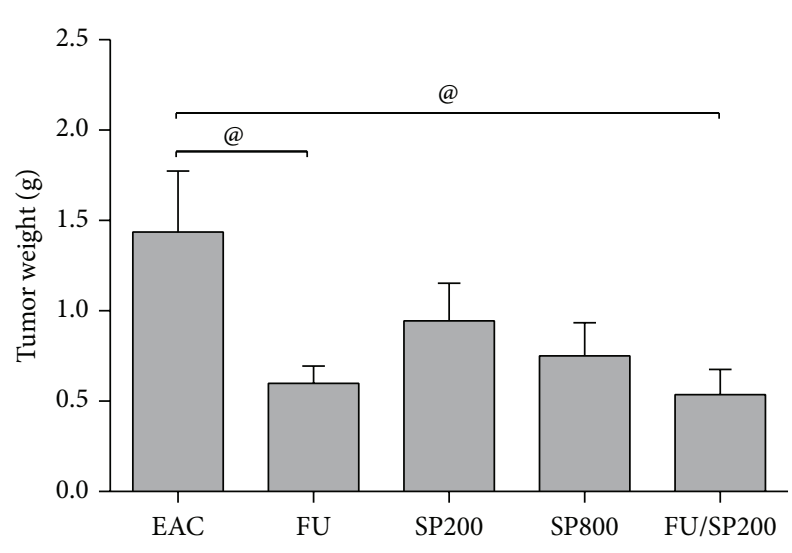

(b)

FIGURE 1: Effect of 5-fluorouracil (20 mg/kg), spirulina (200 or $800 \mathrm{mg} / \mathrm{kg}$ ), and their combination on tumor volume (a) and tumor weight (b) of EAC tumor-bearing mice $(n=5-9)$. EAC: Ehrlich ascites carcinoma tumor-bearing mice; FU: Ehrlich ascites carcinoma tumor-bearing mice treated with 5-fluorouracil (20 mg/kg); SP200: Ehrlich ascites carcinoma tumor-bearing mice treated with spirulina (200 mg/kg); SP800: Ehrlich ascites carcinoma tumor-bearing mice treated with spirulina $(800 \mathrm{mg} / \mathrm{kg})$; FU/SP200: Ehrlich ascites carcinoma tumor-bearing mice treated with 5 -fluorouracil $(20 \mathrm{mg} / \mathrm{kg})$ plus spirulina $(200 \mathrm{mg} / \mathrm{kg})$. Data are expressed as mean $\pm \mathrm{SEM}$. Statistical analysis using one-way ANOVA, followed by Dunnett's posttest. ${ }^{\circledR} P<0.05$ versus EAC group.

TABLE 1: Effects of 5-fluorouracil (20 mg/kg), spirulina (200 or $800 \mathrm{mg} / \mathrm{kg}$ ), and their combination on the survival of EAC tumorbearing mice.

\begin{tabular}{|c|c|c|c|}
\hline Group & Number tested & Survivors/total mice & \% Mortality \\
\hline $\mathrm{EAC}^{\mathrm{a}}$ & 10 & $9 / 10$ & $10 \%$ \\
\hline $\mathrm{FU}^{\mathrm{b}}$ & 10 & $9 / 10$ & $10 \%$ \\
\hline SP200 ${ }^{c}$ & 10 & $5 / 10$ & $50 \%$ \\
\hline SP800 & 10 & $7 / 10$ & $30 \%$ \\
\hline $\mathrm{FU} / \mathrm{SP} 200^{\mathrm{e}}$ & 10 & $5 / 10$ & $50 \%$ \\
\hline $\mathrm{FU} / \mathrm{SP} 800^{\mathrm{f}}$ & 10 & $1 / 10$ & $90 \%$ \\
\hline
\end{tabular}

${ }^{a}$ EAC: Ehrlich ascites carcinoma tumor-bearing mice; ${ }^{b} \mathrm{FU}$ : Ehrlich ascites carcinoma tumor-bearing mice treated with 5 -fluorouracil $(20 \mathrm{mg} / \mathrm{kg})$; ${ }^{\mathrm{c} S P 200:}$ Ehrlich ascites carcinoma tumor-bearing mice treated with spirulina $(200 \mathrm{mg} / \mathrm{kg}) ;{ }^{\mathrm{d}}$ SP800: Ehrlich ascites carcinoma tumor-bearing mice treated with spirulina $(800 \mathrm{mg} / \mathrm{kg})$; ${ }^{\mathrm{e}} \mathrm{FU} / \mathrm{SP} 200$ : Ehrlich ascites carcinoma tumor-bearing mice treated with 5 -fluorouracil $(20 \mathrm{mg} / \mathrm{kg})$ plus spirulina $(200 \mathrm{mg} / \mathrm{kg}) ;{ }^{\mathrm{f}} \mathrm{FU} / \mathrm{SP} 800$ : Ehrlich ascites carcinoma tumor-bearing mice treated with 5-fluorouracil $(20 \mathrm{mg} / \mathrm{kg})$ plus spirulina $(800 \mathrm{mg} / \mathrm{kg})$.

$800 \mathrm{mg} / \mathrm{kg}$ ) resulted in increased mortality rate reaching 50\% and $30 \%$, respectively. Similarly, combined administration of 5-fluorouracil plus spirulina (200 or $800 \mathrm{mg} / \mathrm{kg}$ ) caused a noticeable dose-dependent increase in mortality rate in tumor-bearing mice reaching $50 \%$ and $90 \%$, respectively. Therefore, further assessment of other parameters was not possible from mice that received fluorouracil plus spirulina $(800 \mathrm{mg} / \mathrm{kg})$ due to the high mortality rate $(90 \%)$.

3.2. Effect on Tumor Weight and Volume. As depicted in Figure 1, administration of 5-fluorouracil significantly reduced tumor volume $(-49.7 \%)$ and weight $(-58.3 \%)$ compared to untreated EAC tumor-bearing mice $(P<0.05)$. On the other hand, treatment of tumor-bearing mice with spirulina (200 or $800 \mathrm{mg} / \mathrm{kg}$ ) did not significantly reduce either the tumor volume or tumor weight. Combined administration of 5-fluorouracil plus spirulina $(200 \mathrm{mg} / \mathrm{kg})$ diminished tumor growth as indicated by the significant reduction of tumor volume $(-51.5 \%)$ and tumor weight $(-62.7 \%)$ compared to untreated EAC tumor-bearing mice $(P<0.05)$. There was no significant difference between mice treated with 5-fluorouracil alone or 5-fluorouracil plus spirulina $(200 \mathrm{mg} / \mathrm{kg})$ regarding tumor volume or weight.

3.3. Effect on Hematological Parameters. Different treatment regimens used in the present study resulted in significant alterations of some hematological parameters compared to untreated tumor-bearing mice, while other parameters were not significantly altered. Hematocrit (HCT) level was significantly reduced by the administration of 5-fluorouracil $(-19.7 \%)$, spirulina $200 \mathrm{mg} / \mathrm{kg}(-22.7 \%)$, spirulina $800 \mathrm{mg} / \mathrm{kg}$ (-19.3\%), or 5-fluorouracil plus spirulina $200 \mathrm{mg} / \mathrm{kg}(-27.7 \%)$ compared to untreated EAC tumor-bearing mice. No significant differences were observed between group 2, treated with 5-fluorouracil alone, and group 5, treated with 5fluorouracil plus spirulina $(200 \mathrm{mg} / \mathrm{kg})$. Similarly, mean corpuscular volume (MCV) of red blood cells (RBCs) was significantly reduced by the administration of 5-fluorouracil (-10\%), spirulina $200 \mathrm{mg} / \mathrm{kg}(-16.2 \%)$, spirulina $800 \mathrm{mg} / \mathrm{kg}$ (-19.7\%), or 5-fluorouracil plus spirulina $200 \mathrm{mg} / \mathrm{kg}(-22.3 \%)$ compared to untreated EAC tumor-bearing mice. Mice received 5-fluorouracil plus spirulina $(200 \mathrm{mg} / \mathrm{kg})$ showed a further significant reduction in MCV level when compared to mice treated with 5-fluorouracil alone. From all treatment regimens, only combined administration of 5-fluorouracil plus spirulina $(200 \mathrm{mg} / \mathrm{kg})$ resulted in significant elevation of both platelet count (PT) and plateletcrit (PCT) levels when compared to either untreated EAC tumor-bearing mice or fluorouracil-treated mice (Table 2). 
TABLE 2: Effects of 5-fluorouracil (20 mg/kg), spirulina (200 or $800 \mathrm{mg} / \mathrm{kg}$ ), and their combination on hematological parameters of EAC tumor-bearing mice.

\begin{tabular}{lccccc}
\hline & EAC & FU & SP200 & SP800 & FU/SP200 \\
\hline RBC $\left(10^{12} / \mathrm{L}\right)$ & $7.6 \pm 0.27$ & $6.8 \pm 0.27$ & $6.9 \pm 0.77$ & $7.7 \pm 0.48$ & $7.1 \pm 0.36$ \\
HGB $(\mathrm{g} / \mathrm{L})$ & $11.4 \pm 0.37$ & $9.8 \pm 0.41$ & $10.1 \pm 1.1$ & $10.8 \pm 0.65$ & $10.3 \pm 0.45$ \\
HCT $(\%)$ & $46.8 \pm 1.3$ & $37.6 \pm 1.5^{\mathrm{a}}$ & $36.1 \pm 4.1^{\mathrm{a}}$ & $37.8 \pm 2.3^{\mathrm{a}}$ & $33.8 \pm 1.5^{\mathrm{a}}$ \\
MCV (fL) & $61.5 \pm 0.9$ & $55.3 \pm 2.3^{\mathrm{a}}$ & $51.6 \pm 0.6^{\mathrm{a}}$ & $49.4 \pm 1.5^{\mathrm{a}}$ & $47.8 \pm 1.5^{\mathrm{ab}}$ \\
PT $\left(10^{9} / \mathrm{L}\right)$ & $737 \pm 64$ & $959 \pm 102$ & $947 \pm 39$ & $806 \pm 80$ & $1403 \pm 160^{\mathrm{ab}}$ \\
PCT $(\%)$ & $0.47 \pm 0.05$ & $0.69 \pm 0.08$ & $0.59 \pm 0.04$ & $0.54 \pm 0.07$ & $1.0 \pm 0.12^{\mathrm{ab}}$ \\
WBC $\left(10^{9} / \mathrm{L}\right)$ & $8.1 \pm 0.81$ & $6.2 \pm 1.4$ & $10.2 \pm 2.1$ & $10.7 \pm 2.0$ & $8.9 \pm 3.3$ \\
LYM $\left(10^{9} / \mathrm{L}\right)$ & $7.3 \pm 0.75$ & $4.9 \pm 0.97$ & $7.8 \pm 1.6$ & $7.3 \pm 1.3$ & $6.9 \pm 2.3$ \\
GRA $\left(10^{9} / \mathrm{L}\right)$ & $0.28 \pm 0.08$ & $0.41 \pm 0.17$ & $0.48 \pm 0.19$ & $0.55 \pm 0.19$ & $0.53 \pm 0.27$ \\
\hline
\end{tabular}

Values are expressed as mean \pm SEM $(n=5-9)$. EAC: Ehrlich ascites carcinoma tumor-bearing mice; FU: Ehrlich ascites carcinoma tumor-bearing mice treated with 5 -fluorouracil $(20 \mathrm{mg} / \mathrm{kg})$; SP200: Ehrlich ascites carcinoma tumor-bearing mice treated with spirulina (200 mg/kg); SP800: Ehrlich ascites carcinoma tumor-bearing mice treated with spirulina $(800 \mathrm{mg} / \mathrm{kg}) ; \mathrm{FU} / \mathrm{SP} 200$ : Ehrlich ascites carcinoma tumor-bearing mice treated with 5 -fluorouracil (20 mg/kg) plus spirulina (200 mg/kg). RBC: red blood cell count; HGB: hemoglobin; HCT: hematocrit; MCV: mean corpuscular volume; PT: platelet count; PCT: plateletcrit; WBC: white blood cell count; LYM: lymphocyte count; GRA: granulocyte count. Statistical analysis using one-way ANOVA, followed by Dunnett's posttest. ${ }^{\mathrm{a}} P<0.05$ versus EAC and ${ }^{\mathrm{b}} P<0.05$ versus FU.

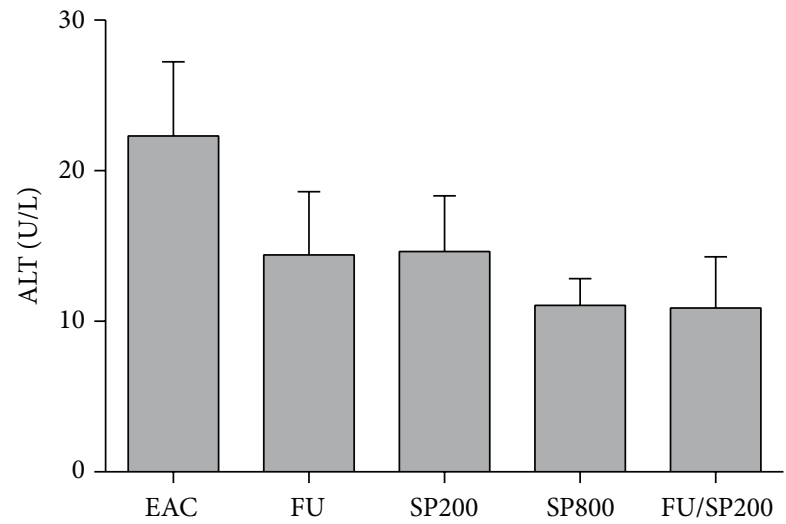

FIGURE 2: Effect of 5-fluorouracil $(20 \mathrm{mg} / \mathrm{kg}$ ), spirulina (200 or $800 \mathrm{mg} / \mathrm{kg}$ ), and their combination on ALT level of EAC tumorbearing mice $(n=4)$. ALT: alanine transaminase; EAC: Ehrlich ascites carcinoma tumor-bearing mice; FU: Ehrlich ascites carcinoma tumor-bearing mice treated with 5 -fluorouracil $(20 \mathrm{mg} / \mathrm{kg})$; SP200: Ehrlich ascites carcinoma tumor-bearing mice treated with spirulina $(200 \mathrm{mg} / \mathrm{kg})$; SP800: Ehrlich ascites carcinoma tumorbearing mice treated with spirulina ( $800 \mathrm{mg} / \mathrm{kg})$; FU/SP200: Ehrlich ascites carcinoma tumor-bearing mice treated with 5 -fluorouracil $(20 \mathrm{mg} / \mathrm{kg})$ plus spirulina $(200 \mathrm{mg} / \mathrm{kg})$. Data are expressed as mean \pm SEM. Statistical analysis using one-way ANOVA, followed by Dunnett's posttest.

3.4. Effect on ALT. In our attempt to identify the cause of the increased mortality associated with the combined administration of fluorouracil and spirulina, we measured the changes in ALT levels. As shown in Figure 2, administration of different drugs resulted in reduction of ALT level when compared to untreated tumor-bearing mice. Nevertheless, this difference does not reach statistical significance. In addition, we did not notice any significant differences in ALT level between mice treated with fluorouracil alone and mice treated with spirulina alone $(200$ or $800 \mathrm{mg} / \mathrm{kg}$ ) or fluorouracil plus spirulina $(200 \mathrm{mg} / \mathrm{kg})$.
3.5. Histopathological Examination. Examination of untreated tumor-bearing mice showed that EAC cells infiltrated and mostly replaced the subcutaneous tissue with necrosis of the remaining skeletal muscles. Numerous newly formed blood capillaries (neovascularization) were seen in the surrounding tissue with mild or no inflammatory response. Such tumor showed tissue architectural disarray, as well as marked degree of cellular anaplasia, pleomorphism, and anisocytosis, with nuclear vesicularity, atypicality, hyperchromasia, and mitoses. Some tumor cells were differentiated into gland-like structures surrounding a lumen containing eosinophilic material. Minimum necrotic areas with pyknosis and karyolysis, which appeared markedly in the central regions of the tumors, were noticed as well as few round-cell infiltrations and hemorrhage (Figures 3(a) and 3(b)).

On the other hand, mice treated with 5-flurourocil revealed minimal tumor cell infiltrations, extensive necrosis, and apoptosis at the margin of the tumor with destructed blood vessels and hemorrhage. Huge numbers of round cells of mostly lymphocytes and macrophages invaded the necrotic areas. Areas of the subcutaneous muscles were normal and others showed fibrous connective tissue proliferation infiltrated with leukocytes (Figures 3(c) and 3(d)).

Mice treated with spirulina alone $(200$ or $800 \mathrm{mg} / \mathrm{kg}$ ) showed similar degree of infiltration as described with untreated tumor-bearing mice. Minimum necrosis and high vascularity of newly formed blood capillaries were also noticed. The inflammatory cell responses and necrosis in comparison with EAC were slightly increased, particularly with the higher dose of $800 \mathrm{mg} / \mathrm{kg}$ (Figures 3(e)-3(h)).

The tumor mass in mice treated with 5 -flurouracil plus spirulina $(200 \mathrm{mg} / \mathrm{kg}$ ) was mostly necrotic (60-70\%). In some parts, this was accompanied by a marked proliferation of fibrotic tissues as regeneration attempts of the subcutaneous tissue. Intense leukocyte aggregations, edema, and hemorrhage were visualized (Figures 3(i) and 3(j)). A scoring of histopathological findings is summarized in Table 3. 


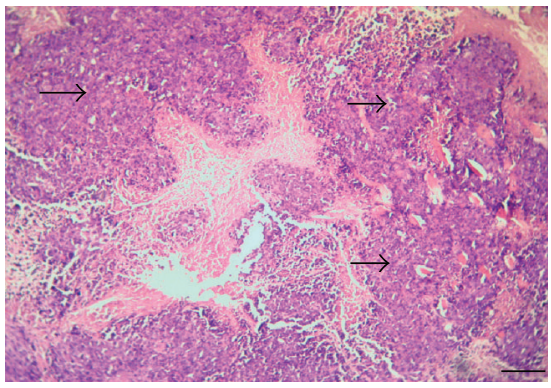

(a)

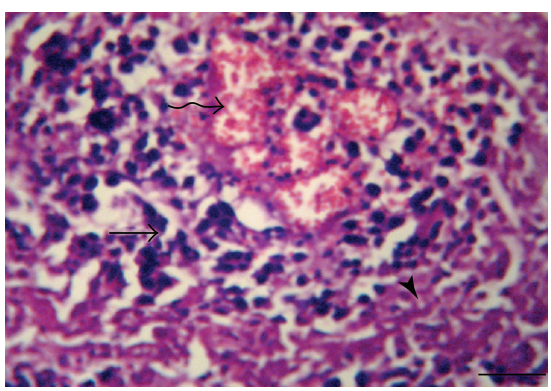

(d)

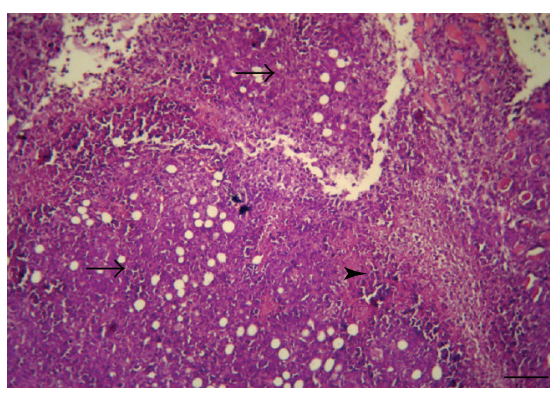

(g)

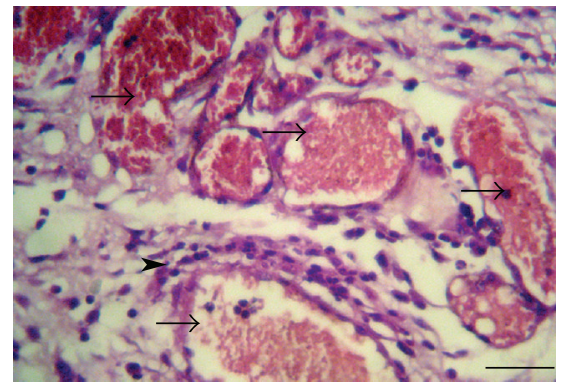

(b)

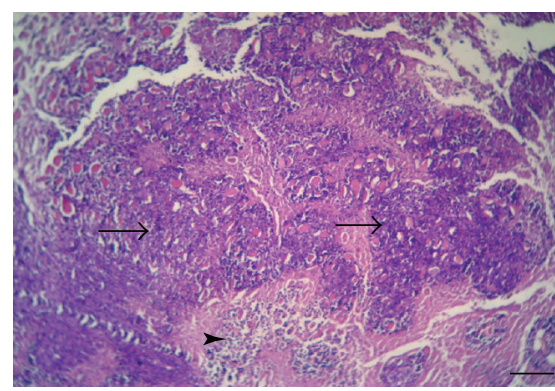

(e)

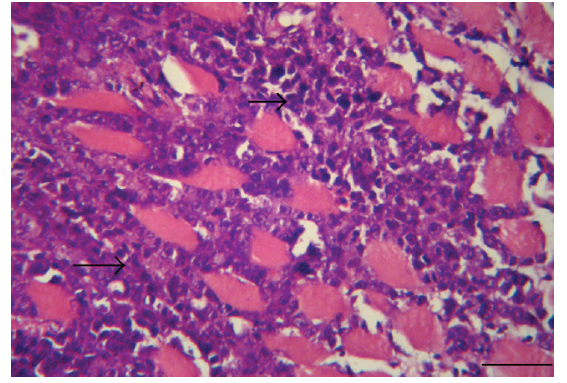

(h)

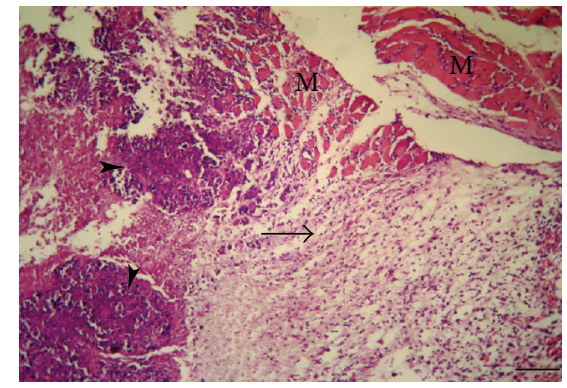

(c)

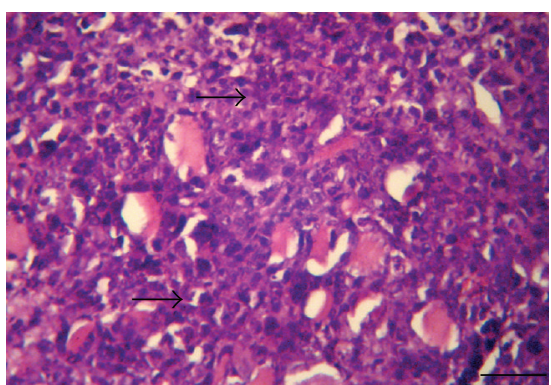

(f)

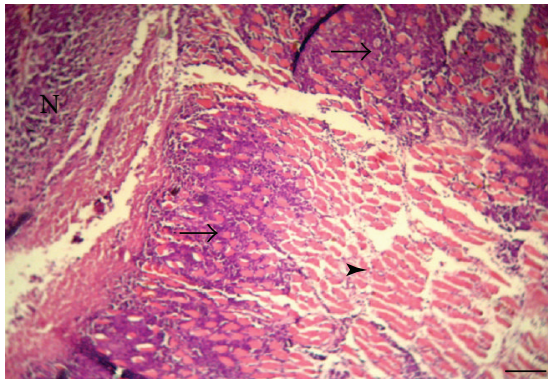

(i)

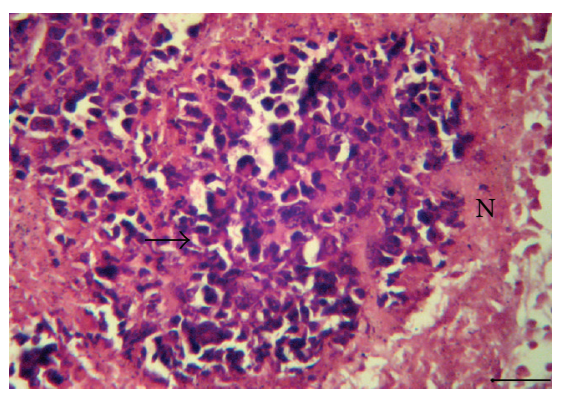

(j)

FIGURE 3: Histopathological examination of Ehrlich ascites carcinoma (EAC) solid tumor. Representative sections were obtained from (a) untreated EAC-bearing mice (arrows: infiltration of subcutaneous tissue with tumor cells), (b) untreated EAC-bearing mice (arrows: newly formed blood capillaries; arrowheads: leukocyte infiltration), (c) EAC tumor-bearing mice treated with 5-fluorouracil $20 \mathrm{mg} / \mathrm{kg}$ (arrowheads: extensive necrosis; arrow: fibrosis; M: skeletal muscles), (d) EAC tumor-bearing mice treated with 5-fluorouracil $20 \mathrm{mg} / \mathrm{kg}$ (irregular arrow: destructed blood vessels and hemorrhage), (e) EAC tumor-bearing mice treated with spirulina $200 \mathrm{mg} / \mathrm{kg}$ (arrows: extensive infiltration of the subcutaneous tissue with tumor cells), (f) EAC tumor-bearing mice treated with spirulina $200 \mathrm{mg} / \mathrm{kg}$ (arrows: tumor cells with cellular anaplasia and anisocytosis), (g) EAC tumor-bearing mice treated with spirulina $800 \mathrm{mg} / \mathrm{kg}$ (arrows: moderate infiltration of the tumor cells; arrowhead: numerous leukocyte infiltration), (h) EAC tumor-bearing mice treated with spirulina $800 \mathrm{mg} / \mathrm{kg}$ (arrows: huge numbers of tumor cells infiltrating the skeletal muscles), (i) EAC tumor-bearing mice treated with 5-fluorouracil $20 \mathrm{mg} / \mathrm{kg}$ plus spirulina $200 \mathrm{mg} / \mathrm{kg}$ (arrows: less infiltration with tumor cells; $\mathrm{N}$ : extensive necrosis and fibrosis), and (j) EAC tumor-bearing mice treated with 5-fluorouracil $20 \mathrm{mg} / \mathrm{kg}$ plus spirulina $200 \mathrm{mg} / \mathrm{kg}$ (arrows: islets of viable tumor cells; $\mathrm{N}$ : extensive necrosis). Sections were stained with HE dyes (scale bar $=50 \mu \mathrm{M}$ ). 
TABLE 3: Histopathology scoring of tumor-bearing mice treated with 5 -fluorouracil (20 mg/kg), spirulina (200 or $800 \mathrm{mg} / \mathrm{kg}$ ), and their combination.

\begin{tabular}{lcccc}
\hline & Necrosis & Neovascularization & Leukocytes & Fibrosis \\
\hline EAC $^{\mathrm{a}}$ & $8-12 \%$ & +++ & + & - \\
FU $^{\mathrm{b}}$ & $50-60 \%$ & + & +++ & ++ \\
SP200 $^{\mathrm{c}}$ & $10-15 \%$ & +++ & ++ & - \\
SP800 $^{\mathrm{d}}$ & $10-15 \%$ & +++ & ++ & - \\
FU $_{\text {SP200 }}$ & $60-70 \%$ & + & +++ & +++ \\
\hline
\end{tabular}

${ }^{a}$ EAC: Ehrlich ascites carcinoma tumor-bearing mice; ${ }^{b} \mathrm{FU}$ : Ehrlich ascites carcinoma tumor-bearing mice treated with 5 -fluorouracil $(20 \mathrm{mg} / \mathrm{kg})$; ${ }^{c}$ SP200: Ehrlich ascites carcinoma tumor-bearing mice treated with spirulina $(200 \mathrm{mg} / \mathrm{kg})$; ${ }^{\mathrm{d}} \mathrm{SP} 800$ : Ehrlich ascites carcinoma tumor-bearing mice treated with spirulina $(800 \mathrm{mg} / \mathrm{kg}) ;{ }^{\mathrm{e}} \mathrm{FU} / \mathrm{SP} 200$ : Ehrlich ascites carcinoma tumor-bearing mice treated with 5 -fluorouracil $(20 \mathrm{mg} / \mathrm{kg})$ plus spirulina $(200 \mathrm{mg} / \mathrm{kg}) .(-)$ none; (+) mild; (++) moderate; $(+++)$ severe; $(++++)$ more severe.

\section{Discussion}

Adjuvant and neoadjuvant chemotherapy represent important approaches in the management of cancer in order to reduce the recurrence following surgery or to reduce the tumor size enough to allow successful surgical removal [20, 21]. Considering various side effects caused by chemotherapeutic agents, development of new effective anticancer drugs is needed [22]. Increased attention is directed towards natural products as promising sources of anticancer therapeutic agents [23].

Spirulina is a plankton alga or cyanobacterium, which has been used as a food supplement for a long time [6, 24]. Spirulina exerts a wide array of pharmacological effects including anti-inflammatory, antioxidant, anticancer, and hepatoprotective properties $[25,26]$. Therefore, in this study, we examined the effect of spirulina against Ehrlich solid tumor induced experimentally in mice.

Untreated mice inoculated with EAC cells intramuscularly in the right thigh of the hind limb developed a palpable solid tumor in 13 days following inoculation. This is consistent with other previous studies that used the same model $[18,27]$. Administration of 5 -fluorouracil $(20 \mathrm{mg} / \mathrm{kg})$ for 9 consecutive days starting from day 1 following EAC cells inoculation significantly reduced both tumor volume and tumor weight compared to untreated EAC tumor-bearing mice. On the other hand, administration of spirulina alone (200 or $800 \mathrm{mg} / \mathrm{kg}$ ) did not significantly alter the tumor size compared to untreated EAC tumor-bearing mice. Although spirulina showed a dose-dependent tendency towards reducing the tumor volume, however, such change was not significant. These results reveal that spirulina alone lacks antitumor effect in this experimental model. We assume that this lack of activity is not attributed to the use of small doses of spirulina because even at a dose of $800 \mathrm{mg} / \mathrm{kg}$ no effect was observed. In addition, we rule out poor oral absorption of spirulina as a possible cause of the lack of the antitumor effect based on previous reports showing good bioavailability of different constituents of spirulina including carotenoids [28-30], iron [31], and proteins [32]. This lack of effect can be viewed also at the histopathological level. Tumor specimen from mice treated with spirulina alone (200 or $800 \mathrm{mg} / \mathrm{kg}$ ) showed EAC cells that infiltrated and mostly replaced the subcutaneous tissue. The observed degree of infiltration was similar to that found in specimens from untreated tumor-bearing mice. In addition, minimum necrosis was noticed in EAC tumorbearing mice treated with spirulina alone at both dose levels (10-15\%), which is very close to untreated mice (8-12\%).

The lack of the antitumor effect of spirulina in our model does not conform to some other reports that described a potential anticancer activity of spirulina in other experimental models. Yogianti et al. [33] showed that spirulina exerts antitumor effects against UVB-induced skin tumor development in mice. In addition, it has been reported that spirulina exerts a chemopreventive effect against 7,12-dimethylbenz[a]anthracene-induced breast carcinogenesis [34] and against dibutyl nitrosamine-induced liver cytotoxicity and carcinogenesis [12] in rat. The discrepancy between these data and our results might be attributed to differences in the experimental conditions, the model of the solid tumor used, or the limited ability of spirulina to penetrate through Ehrlich solid tumor tissue and to reach all of the tumor cells in a potentially lethal concentration. The latter has been recognized as an important cause of anticancer drug resistance [35].

On the other hand, mice treated with 5-flurourocil alone showed minimal tumor cell infiltrations and extensive necrosis (50-60\%). To test whether spirulina can at least potentiate the antitumor effect of fluorouracil, we examined the effect of their combined administration. Fluorouracil plus spirulina $(200 \mathrm{mg} / \mathrm{kg}$ ) significantly reduced both tumor volume and weight compared to untreated tumor-bearing mice; however, there were no significant differences in tumor volume or weight compared to mice treated with fluorouracil alone. In addition, histopathological examination revealed that the tumor mass in mice treated with both 5-flurouracil and spirulina $(200 \mathrm{mg} / \mathrm{kg})$ was mostly necrotic (60-70\%) comparable to fluorouracil alone.

Interestingly, we observed a substantial, dose-dependent increase in mortality rate in mice treated with fluorouracil plus spirulina at a dose of $200 \mathrm{mg} / \mathrm{kg}$ (5 out of 10) and fluorouracil plus spirulina at a dose of $800 \mathrm{mg} / \mathrm{kg}$ (9 out of 10). We assume that this toxic effect is not attributed to EACtumor development per se or fluorouracil administration per se because only one animal died from group 1 (EAC-bearing mice) and group 2 (fluorouracil-treated mice). Therefore, it seems that the combined administration of fluorouracil and spirulina concurrently is responsible for such toxic effect.

We tried further to explain the mechanism implicated in the increased mortality by examining the effect on some hematological parameters and ALT level to see if this combination can cause acute hemotoxicity or fulminant hepatic damage. No significant alterations in complete blood count (CBC) were observed except for reduction in mean corpuscular volume $(\mathrm{MCV})$ and increase in platelet count (PT) and plateletcrit (PCT) in mice treated with fluorouracil plus spirulina $(200 \mathrm{mg} / \mathrm{kg})$ when compared to mice treated with fluorouracil alone. In addition, there was no significant difference in ALT level between both groups. These results 
rule out hemotoxicity or hepatotoxicity as possible causes of increased mortality.

Depending on the present available results, the underlying mechanism of increased mortality is yet elusive; however, some postulations are worth mentioning. Different reports described a hypotensive effect associated with the administration of either 5-fluorouracil [36-38] or spirulina [39]. It is likely that combined administration of fluorouracil and spirulina, particularly at high dose level of $800 \mathrm{mg} / \mathrm{kg}$, could enhance the reduction of blood pressure and might result in cardiovascular collapse. On the other hand, spirulina may have increased fluorouracil toxicity because of possible inhibition of the activity of dihydropyrimidine dehydrogenase, the enzyme that catalyzes the first rate-limiting step of fluorouracil degradation [40]. This assumption is based on a previous study reporting that spirulina resulted in inhibition of activities of some hepatic cytochrome P450 enzymes [41]. Although we could not find any report in the literature describing a direct relation between spirulina and dihydropyrimidine dehydrogenase, a possible effect could still be expected. Certainly, these assumptions need to be thoroughly investigated.

In conclusion, the present study describes the lack of antitumor activity of spirulina in EAC tumor-bearing mice model. In addition, spirulina administered simultaneously with fluorouracil did not enhance the antitumor activity of the later but rather resulted in increased dose-dependent mortality. In light of the present results, the mechanism of spirulina-induced mortality is not well understood. Although spirulina has been shown to possess anticancer effects in other models, the present study shows that it might not be a suitable therapeutic alternative for conventional chemotherapeutic agents in all settings such as EAC tumor-bearing mice model. In addition, spirulina might be not very safe, particularly when administered with other drugs such as fluorouracil. Therefore, we recommend that spirulina, or even other natural products, should be used cautiously and that possible interactions with other coadministered drugs should be monitored carefully.

\section{Conflict of Interests}

The authors declare that there is no conflict of interests.

\section{Acknowledgment}

The authors acknowledge Dr. Mohamed Hamed Mohamed, Professor of Pathology, Faculty of Veterinary Medicine, Zagazig University, for the histopathological examination.

\section{References}

[1] A. A. Stavrovskaya, "Cellular mechanisms of multidrug resistance of tumor cells," Biochemistry, vol. 65, no. 1, pp. 95-106, 2000.

[2] C. Moorthi, R. Manavalan, and K. Kathiresan, "Nanotherapeutics to overcome conventional cancer chemotherapy limitations," Journal of Pharmacy and Pharmaceutical Sciences, vol. 14, no. 1, pp. 67-77, 2011.
[3] G. M. Cragg and D. J. Newman, "Plants as a source of anticancer agents," Journal of Ethnopharmacology, vol. 100, no. 1-2, pp. 72-79, 2005.

[4] D. J. Newman, G. M. Cragg, and K. M. Snader, "Natural products as sources of new drugs over the period 1981-2002," Journal of Natural Products, vol. 66, no. 7, pp. 1022-1037, 2003.

[5] G. Chamorro, M. Salazar, L. Favila, and H. Bourges, "Pharmacology and toxicology of Spirulina alga," Revista de Investigación Clínica, vol. 48, no. 5, pp. 389-399, 1996.

[6] J. E. Piero Estrada, P. Bermejo Bescós, and A. M. Villar del Fresno, "Antioxidant activity of different fractions of Spirulina platensis protean extract," Farmaco, vol. 56, no. 5-7, pp. 497-500, 2001.

[7] C. Romay, J. Armesto, D. Remirez, R. González, N. Ledon, and I. García, "Antioxidant and anti-inflammatory properties of Cphycocyanin from blue-green algae," Inflammation Research, vol. 47 , no. 1, pp. 36-41, 1998.

[8] B. B. Vadiraja, N. W. Gaikwad, and K. M. Madyastha, "Hepatoprotective effect of C-phycocyanin: protection for carbon tetrachloride and R-(+)-pulegone-mediated hepatotoxicty in rats," Biochemical and Biophysical Research Communications, vol. 249, no. 2, pp. 428-431, 1998.

[9] K. R. Roy, K. M. Arunasree, N. P. Reddy, B. Dheeraj, G. V. Reddy, and P. Reddanna, "Alteration of mitochondrial membrane potential by Spirulina platensis C-phycocyanin induces apoptosis in the doxorubicinresistant human hepatocellularcarcinoma cell line HepG2," Biotechnology and Applied Biochemistry, vol. 47, no. 3, pp. 159-167, 2007.

[10] T. Mishima, J. Murata, M. Toyoshima et al., "Inhibition of tumor invasion and metastasis by calcium spirulan (Ca-SP), a novel sulfated polysaccharide derived from a blue-green alga, Spirulina platensis," Clinical and Experimental Metastasis, vol. 16, no. 6, pp. 541-550, 1998.

[11] J. Schwartz and G. Shklar, "Regression of experimental hamster cancer by beta carotene and algae extracts," Journal of Oral and Maxillofacial Surgery, vol. 45, no. 6, pp. 510-515, 1987.

[12] M. F. Ismail, D. A. Ali, A. Fernando et al., "Chemoprevention of rat liver toxicity and carcinogenesis by Spirulina," International Journal of Biological Sciences, vol. 5, no. 4, pp. 377-387, 2009.

[13] M. Ozaslan, I. D. Karagoz, I. H. Kilic, and M. E. Guldur, "Ehrlich ascites carcinoma," African Journal of Biotechnology, vol. 10, no. 13, pp. 2375-2378, 2011.

[14] S. L. Da Silva, J. D. S. Chaar, and T. Yano, "Chemotherapeutic potential of two gallic acid derivative compounds from leaves of Casearia sylvestris Sw (Flacourtiaceae)," European Journal of Pharmacology, vol. 608, no. 1-3, pp. 76-83, 2009.

[15] A. M. Kabel, M. N. Abdel-Rahman, A. E.-D. E. El-Sisi, M. S. Haleem, N. M. Ezzat, and M. A. El Rashidy, "Effect of atorvastatin and methotrexate on solid Ehrlich tumor," European Journal of Pharmacology, vol. 713, no. 1-3, pp. 47-53, 2013.

[16] E. Noaman, N. K. Badr El-Din, M. A. Bibars, A. A. Abou Mossallam, and M. Ghoneum, "Antioxidant potential by arabinoxylan rice bran, MGN-3/biobran, represents a mechanism for its oncostatic effect against murine solid Ehrlich carcinoma," Cancer Letters, vol. 268, no. 2, pp. 348-359, 2008.

[17] G. Chamorro-Cevallos, L. Garduño-Siciliano, B. L. Barrón, E. Madrigal-Bujaidar, D. E. Cruz-Vega, and N. Pages, "Chemoprotective effect of Spirulina (Arthrospira) against cyclophosphamide-induced mutagenicity in mice," Food and Chemical Toxicology, vol. 46, no. 2, pp. 567-574, 2008.

[18] M. Mandal, S. K. Jaganathan, D. Mondhe, Z. A. Wani, and H. C. Pal, "Effect of honey and eugenol on ehrlich ascites and solid 
carcinoma," Journal of Biomedicine and Biotechnology, vol. 2010, Article ID 989163, 5 pages, 2010.

[19] D. A. Sorg and B. Buckner, "A simple method of obtaining venous blood from small laboratory animals," Proceedings of the Society for Experimental Biology and Medicine, vol. 115, pp. 11311132, 1964.

[20] B. Fisher, J. Bryant, N. Wolmark et al., "Effect of preoperative chemotherapy on the outcome of women with operable breast cancer," Journal of Clinical Oncology, vol. 16, no. 8, pp. 26722685, 1998.

[21] D. Mauri, N. Pavlidis, and J. P. A. Ioannidis, "Neoadjuvant versus adjuvant systemic treatment in breast cancer: a metaanalysis," Journal of the National Cancer Institute, vol. 97, no. 3, pp. 188-194, 2005.

[22] S. Coseri, "Natural products and their analogues as efficient anticancer drugs," Mini-Reviews in Medicinal Chemistry, vol. 9, no. 5, pp. 560-571, 2009.

[23] D. J. Newman, "Natural products as leads to potential drugs: an old process or the new hope for drug discovery?" Journal of Medicinal Chemistry, vol. 51, no. 9, pp. 2589-2599, 2008.

[24] J. C. Dillon, A. P. Phuc, and J. P. Dubacq, "Nutritional value of the alga Spirulina," World Review of Nutrition and Dietetics, vol. 77, pp. 32-46, 1995.

[25] V. B. Bhat and K. M. Madyastha, "C-Phycocyanin: a potent peroxyl radical scavenger in vivo and in vitro," Biochemical and Biophysical Research Communications, vol. 275, no. 1, pp. 20-25, 2000.

[26] J. Subhashini, S. V. K. Mahipal, M. C. Reddy, M. M. Reddy, A. Rachamallu, and P. Reddanna, "Molecular mechanisms in C-Phycocyanin induced apoptosis in human chronic myeloid leukemia cell line-K562," Biochemical Pharmacology, vol. 68, no. 3, pp. 453-462, 2004.

[27] A. El-Moneim Mahmoud Osman, M. M. Sayed Ahmed, M. T. El-Din Khayyal, and M. M. El-Merzabani, "Hyperthermic potentiation of cisplatin cytotoxicity on solid Ehrlich carcinoma," Tumori, vol. 79, no. 4, pp. 268-272, 1993.

[28] R. Kapoor and U. Mehta, "Utilization of $\beta$-carotene from Spirulina platensis by rats," Plant Foods for Human Nutrition, vol. 43, no. 1, pp. 1-7, 1993.

[29] G. V. Mitchell, E. Grundel, M. Jenkins, and S. R. Blakely, "Effects of graded dietary levels of spirulina maxima on vitamins A and E in male rats," Journal of Nutrition, vol. 120, no. 10, pp. 12351240, 1990.

[30] V. Annapurna, N. Shah, P. Bhaskaram, M. S. Bamji, and V. Reddy, "Bioavailability of spirulina carotenes in preschool children," Journal of Clinical Biochemistry and Nutrition, vol. 10, no. 2, pp. 145-151, 1991.

[31] P. E. Johnson and L. E. Shubert, "Availability of iron to rats from spirulina, a blue-green alga," Nutrition Research, vol. 6, no. 1, pp. 85-94, 1986.

[32] C. Santillan, "Cultivation of the Spirulina for human consumption and for animal feed," in Proceedings of the International Congress of Food Science and Technology, Madrid, Spain, September 1974.

[33] F. Yogianti, M. Kunisada, E. Nakano et al., "Inhibitory effects of dietary Spirulina platensis on UVB-induced skin inflammatory responses and carcinogenesis," Journal of Investigative Dermatology, vol. 134, pp. 2610-2619, 2014.

[34] A. Ouhtit, M. F. Ismail, A. Othman et al., "Chemoprevention of rat mammary carcinogenesis by spirulina," The American Journal of Pathology, vol. 184, no. 1, pp. 296-303, 2014.
[35] O. Trédan, C. M. Galmarini, K. Patel, and I. F. Tannock, "Drug resistance and the solid tumor microenvironment," Journal of the National Cancer Institute, vol. 99, no. 19, pp. 1441-1454, 2007.

[36] A. Polk, M. Vaage-Nilsen, K. Vistisen, and D. L. Nielsen, "Cardiotoxicity in cancer patients treated with 5-fluorouracil or capecitabine: a systematic review of incidence, manifestations and predisposing factors," Cancer Treatment Reviews, vol. 39, no. 8, pp. 974-984, 2013.

[37] W. J. Gradishar and E. E. Vokes, "5-fluorouracil cardiotoxicity: a critical review," Annals of Oncology, vol. 1, no. 6, pp. 409-414, 1990.

[38] A. A. Jakubowski and N. Kemeny, "Hypotension as a manifestation of cardiotoxicity in three patients receiving cisplatin and 5-fluorouracil," Cancer, vol. 62, no. 2, pp. 266-269, 1988.

[39] G. Hsiao, P. O.-H. Chou, M.-Y. Shen, D.-S. Chou, C.-H. Lin, and J.-R. Sheu, "C-phycocyanin, a very potent and novel platelet aggregation inhibitor from Spirulina platensis," Journal of Agricultural and Food Chemistry, vol. 53, no. 20, pp. 77347740, 2005.

[40] R. B. Diasio and B. E. Harris, "Clinical pharmacology of 5fluorouracil," Clinical Pharmacokinetics, vol. 16, no. 4, pp. 215237, 1989.

[41] S. Savranoglu and T. B. Tumer, "Inhibitory effects of spirulina platensis on carcinogen-activating cytochrome P450 isozymes and potential for drug interactions," International Journal of Toxicology, vol. 32, no. 5, pp. 376-384, 2013. 

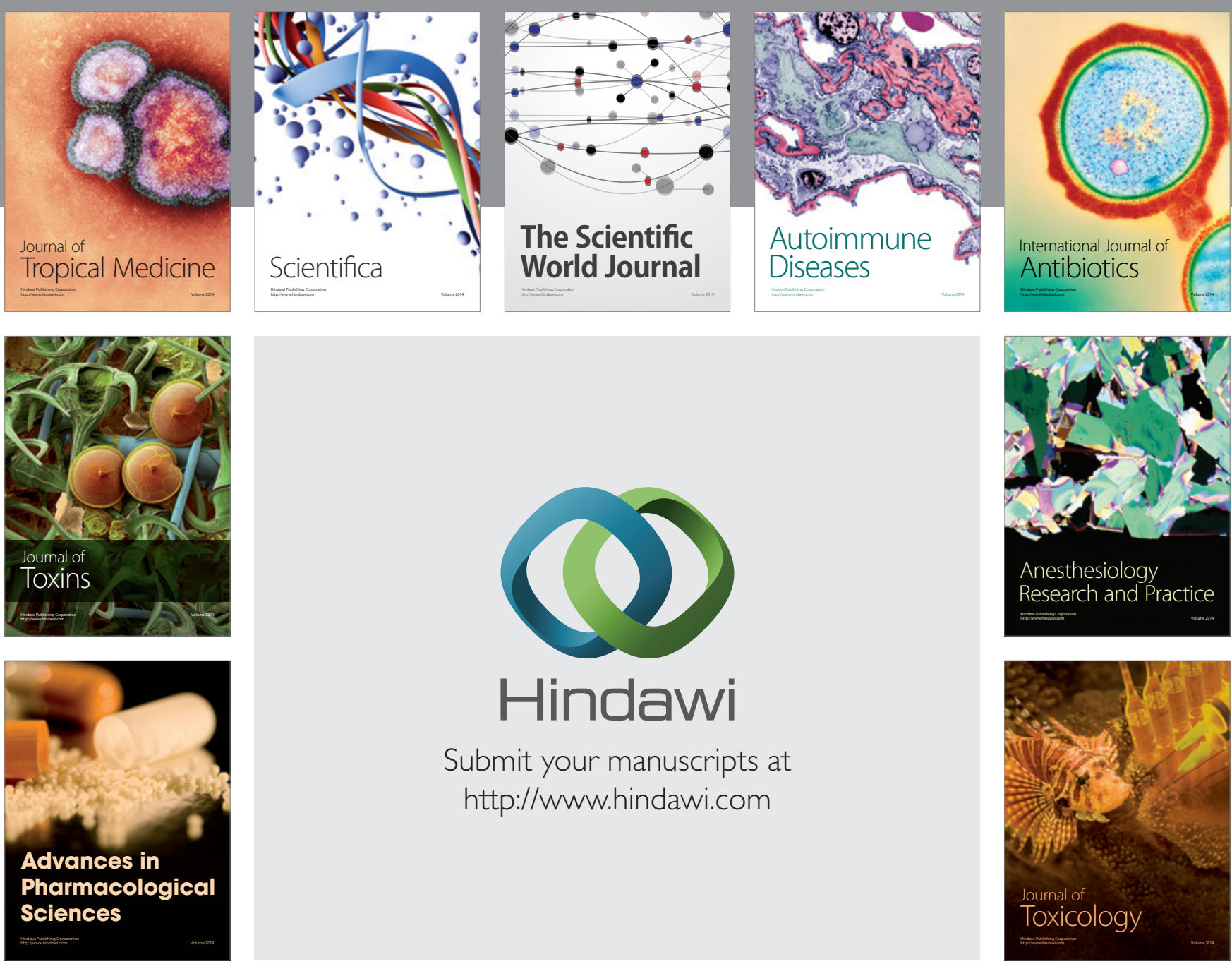

\section{Hindawi}

Submit your manuscripts at

http://www.hindawi.com
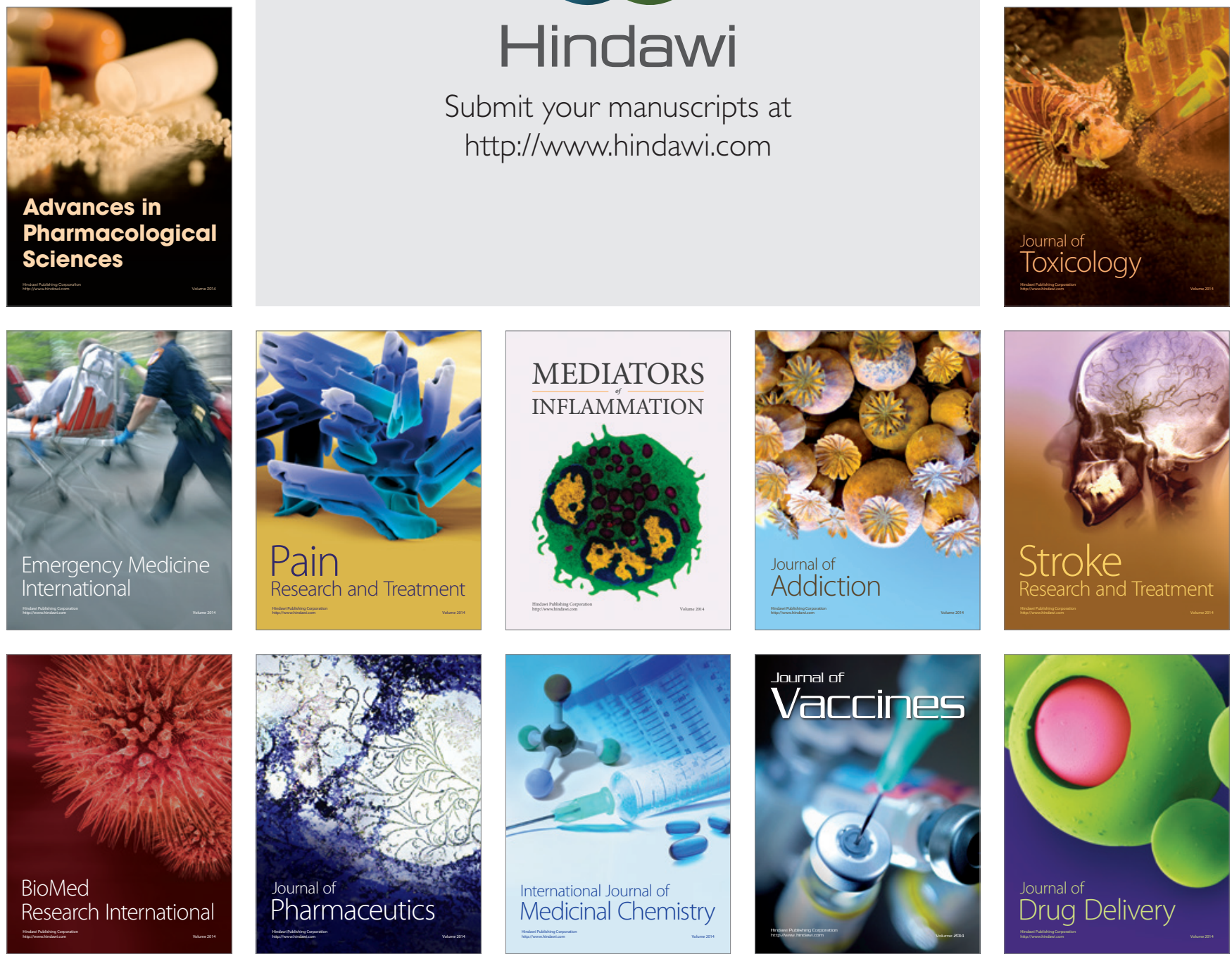